\title{
The Colonisation of South Africa: A unique case
}

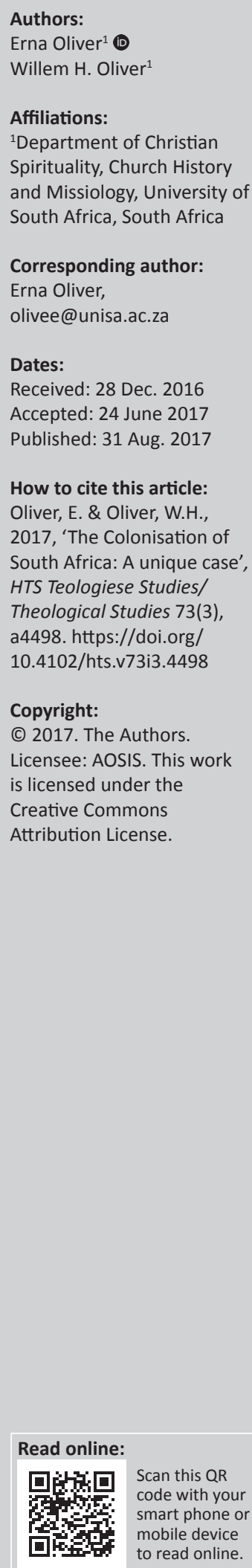

From the 15th century onwards, most of the countries in Africa have been colonised by the European world powers, Great Britain, France, Portugal, Germany, Spain, Italy and Belgium. South Africa was officially colonised in 1652. Apart from the European colonisation being executed from the south of the continent, South Africa also experienced a migration and invasion of people groups from the north. The indigenous people groups, inhabiting the country long before these two groups arrived there, will be discussed as background to the rest of the article. A few factors that made the colonisation of South Africa unique within the African context will be discussed.

\section{Introduction ${ }^{1}$}

\author{
!KE E: /XARRA //KE \\ (Unity in diversity - Khoi phrase on South Africa's coat of arms)
}

This article is written without the intention of entering into an argument as to whom South Africa de facto belongs or the necessity of land restitution that is rife at this moment. The intention is to state the 'facts' of the colonisation ${ }^{2}$ of South Africa from a somehow different angle in order to understand the composition of this country better and to take cognition of the fact that we need to celebrate the notion of a rainbow nation more, instead of fighting for personal or political gain.

During 1884-1885, the Berlin Conference (also called the Congo Conference or West Africa Conference - cf. Heath n.d.) was held at the request of Portugal and organised by German chancellor, Otto von Bismarck. He summoned representatives of all the major Western powers of the world to join in and decide on the control of Africa. The representatives came from AustriaHungary, Belgium, Denmark, France, the United Kingdom, Italy, the Netherlands, Portugal, Spain, Sweden-Norway, the Ottoman Empire and even the United States. This conference formed the pinnacle of the competition between all the powers for territory in Africa and is commonly known as the Scramble for Africa (cf. Pakenham 1991). Within half a century, Europe conquered almost the whole continent (Pakenham 1991:xxi). Having read the comprehensive book of Pakenham on how each of the countries in Africa was grabbed by Imperial European powers, especially Great Britain, France, Portugal, Germany, Italy, Spain and Belgium, it becomes evident that every country in Africa has a unique story about its colonisation, even Ethiopia who was only colonised for a very short period of time by Italy (1936-1941) and Liberia who was colonised during the first half of the 19th century. South Africa most certainly has its own unique story.

The year 1994 was a ground-breaking year for South Africa when this country became a Democracy with the ANC's Dr Nelson Mandela as the first democratically elected president. The Democracy was, however, preceded by migrations and invasions of black people for longer than a millennium, as well as a little more than three centuries of European occupation. The migrations and invasions of people groups took place from the north of the continent, moving to the south, while the Europeans occupied the country from the south. The two European countries who occupied the land were the Netherlands (1652-1795 and 1803-1806) and Great Britain (1795-1803 and 1806-1961). Although South Africa became a Union with its own white people government in 1910, the country was still regarded as a colony of Britain till 1961. After the Second World War, in 1948, the National Party won the elections in South Africa, marking

\footnotetext{
1.This article was presented as a paper at the AHA Conference in Sydney 2015. It was done with full cognition of how History is presented in the classroom today. According to the National Curriculum Statement (Department of Education 2000), the aim of the post-apartheid curriculum is to permit the unofficial and the hidden to become visible "through a commitment to the idea that historical "truth" can be subjected to rigorous analysis by providing opportunities for "border crossing"' (Wilmot \& Naidoo 2011:28; cf. Vestergaard be subjected to rigorous analysis by
2001:24-26; Weldon 2009:177-189).

2.The terms 'colonised' and 'colonisation' in this article are understood as an action or venture to establish political control over a place or land, to settle among and establish control over the indigenous people of an area and to appropriate a place or domain for one's
} own use (Oxford Dictionaries 2015). 
the beginning of white Afrikaner rule in the country under the supervision of Britain. The year 1961, when South Africa became a republic, witnessed the introduction of more than three decades of white Afrikaner supremacy over the black people in the country, independent of Britain (cf. Heldring \& Robinson 2012).

This article focuses on the uniqueness of the colonisation of South Africa. The earliest inhabitants of the country will be discussed, serving as background to the rest of the article, before we take a look at the 'unofficial colonisers' from the north and the 'official colonisers' from the south. It needs to be stated here that:

far more research has been and is still being done on the subject of colonialism and far more has been published and is still being published on it than on any other theme in African history. (Boahen 2000:16)

It is therefore rather difficult to say something new on the topic.

\section{The earliest inhabitants of the southern parts of Africa}

According to the Big Bang theory, the cosmos had its origin about 13700 million years ago, while earth was created almost 4600 million years ago (Meyer 2012:17). Round about 180000 years ago, Africa was the origin (birthplace) of the modern human species to walk this planet (cf. Oliver 2014:104; Oppenheimer 2003:51). For the past 100000 years, these modern people also resided in the southern parts of Africa before any other humans (South Africa 2015) - long before the people groups from the north and the Europeans from the south came to occupy this part of the continent. Those moderns in the southern parts of Africa 'south of the Zambezi Valley' were called the original San hunter-gatherer groups (Adhikari 2010:21). Meyer (2012:30) restricted their stay in the southern parts of Africa to 20000 years referring to them as the ancestors of the Khoisan, while Giliomee and Mbenga (2007:6) argued that they entered this part of Africa only 14000 years ago. These were the indigenous people of this part of the continent.

The Khoisan consisted of two main groups, called the San (they were called Bushmen by the Dutch - cf. Giliomee \& Mbenga 2007:19) and the Khoi-Khoi, also called the Khoekhoe or Khoekhoen, whom the Dutch referred to as Hottentots (Giliomee \& Mbenga 2007:19). Physical anthropologists are using the term Khoisan to 'distinguish the aboriginal people of southern Africa from their black African farming neighbours' (South Africa 2015). The San people groups travelled all over the southern parts of Africa hunting game, while the pastoral Khoekhoe(n) tribes were found in areas with water and enough grazing. They acquired their livestock from the people groups living in Botswana (Giliomee \& Mbenga 2007:19) and became prosperous cattle farmers. Already as early as the 1590s they traded with the English and Dutch mariners who sailed from Europe to the East and back. They traded their cattle and sheep for copper, iron and tobacco (cf. Giliomee \& Mbenga 2007:21).
The San was the first people group to come in contact with the Dutch in the south of the continent. When the latter started to invade the southern parts of Africa (which they called the Cape), the Khoi-Khoi settlements were already limited to the southern parts of the country (Giliomee \& Mbenga 2007:19):

- The Namaqua group lived in the present north-eastern Cape.

- The Korana group lived along the Orange River.

- The Gonaqua 'interspersed' among the Xhosa groups in the present Eastern Cape.

- The largest part of the Khoi-Khoi lived in the 'wellwatered pasturelands of the south-western Cape'. ${ }^{3}$

\section{Unique features of the colonisation}

Three unique features of the colonisation will be discussed, namely the way in which South Africa was colonised, the new people group and language that developed because of the colonisation, and lastly the new nation of South Africa.

\section{The colonisation of South Africa}

The colonisation of South Africa is mostly attributed to the Europeans. A closer investigation, however, shows that there is more to it than meets the eye. This is the reason why the colonisation process can actually be divided into three categories, namely an 'unofficial colonisation', two 'official colonisations' and lastly an 'internal colonisation'.

\section{Unofficial colonisation}

About 2000 years ago, some farmer and metalworker groups left North Africa to move southwards through Cameroon and eastern Africa (Meyer 2012:32). In these parts of the continent, and especially in Cameroon, '[f]arming was originally developed' (Giliomee \& Mbenga 2007:22). Some of these groups that moved south, eventually settled in the northern to north-eastern parts of today's South Africa, about 1700 years ago (Giliomee \& Mbenga 2007:22), or between 400 and 800 CE (Meyer 2012:33). In Mapungubwe, adjacent to the Limpopo River (the northern boundary of South Africa) evidence can be found of a kingdom that existed there at approximately 1000-1300 CE. That people group, probably with Venda origins (Giliomee \& Mbenga 2007:31), produced golden artefacts. The groups that settled more southwards, between 1500 and $1800 \mathrm{CE}$, were the ancestors of the Bantuspeaking people groups in South Africa, called the southeastern Bantu (Meyer 2012:33). They settled in the northern, eastern and central parts of South Africa, forming clans with their own identities and hierarchical socio-political rank structures. These groups or clans consisted of the Nguni and the Sotho or Tswana clans living also in Botswana, the Tsonga clans in Mozambique and north-eastern South Africa, the Shona clans in Zimbabwe and their close relatives, the Venda, who arrived in the northern parts of South Africa during the

3.The distinct clicks of their language, once found nowhere else in Africa, have been incorporated into Zulu and Xhosa speech. They have also contributed to the richness incorporated into Zulu and Xhosa speech. They have also contributed to the richness
of Afrikaans and South African English with words such as eina [ouch] and aikhona of Afrikaans and South African English with words such as eina
[absolutely not] and place names like 'Karoo' and 'Keiskamma'. 
18th century, as well as the Lemba, living in small groups with other clans like the Venda and the Sotho in the northern parts of South Africa. The Sotho or Tswana clans originating from Tanzania first occupied and dominated the northern parts of South Africa and by 1500 they expanded more southwards and eastwards in the country (Giliomee \& Mbenga 2007:30).

The Nguni clans originating from the Great Lakes region in eastern Africa and migrating southwards between 900 and 1290 (Giliomee \& Mbenga 2007:29), belonged to one language group, but divided into smaller groups, each with its own cultural character and dialects (Meyer 2012:34). During the 14th century, they moved inland from the present KwaZuluNatal (Giliomee \& Mbenga 2007:29). During the 19th century, they could already be found in the vicinity of Swaziland, north-east and east of Pretoria, in KwaZulu-Natal and the Eastern Cape (Meyer 2012:34). During the 17th century, the Northern Nguni groups could be divided into three groups called the Lala, the Mbo and the Ntungwa (Meyer 2012:34). By 1800, they split up into smaller clans that settled east of Swaziland. The Southern Nguni groups already occupied the territory between the Eastern Cape and KwaZulu-Natal in the vicinity of the Umzinvubu River. The most prominent groups were the Mpondo, Mponomise, Thembu and the Xhosa groups (Meyer 2012:34).

Between the 17th and 19th centuries, the Ndebele clans occupied the northern parts of South Africa, now called Gauteng, Mpumalanga and Limpopo. During the 19th century, the Matabele (followers of Mzilikazi and sometimes mixed up with the Ndebele) left KwaZulu-Natal for the northern parts of South Africa and later on for the western parts of Zimbabwe (Meyer 2012:35). The Sotho clans occupied the interior of South Africa and Botswana. Evidence of them occupying these parts of the country is signalling a time frame between 700 and 1300 CE. The Venda clans already occupied the northern parts of Limpopo during the first half of the 18th century.

According to Giliomee and Mbenga (2007:33), the migrations ${ }^{4}$ inside South Africa can be defined by two terms: Segmentation and differentiation. Segmentation refers to groups who divided into two or more groups, while differentiation refers to a 'process whereby certain individuals came to secure political, social and economic power over others' (Giliomee \& Mbenga 2007:33).

The Khoisan people, together with some black people groups (sometimes called 'negroids' - cf. Giliomee \& Mbenga 2007:36), were the earliest inhabitants of the Highveld to the middle and north of South Africa. Black people groups then invaded that part of the country from the north. The Fokeng people, originally with a Nguni culture, was the product of the interaction between the invaders and the local people. The Sotho or Tswana 'chiefdoms' (Giliomee \& Mbenga

4.The term 'migration' used under this sub-heading implies a rapid movement taking place over a period of hundreds of years, which does not necessarily (but most probably) include the ejection or demolition of other people groups.
2007:36) eventually resulted from these interactions. From there, certain parts of this group moved southwards and ended up in the Northern Cape. After 1750, kinship wars started to break out between the chiefdoms, while other black people groups intervened in these wars and established a stronghold (Giliomee \& Mbenga 2007:36).

The earliest Nguni groups lived along the eastern coast of South Africa in KwaZulu-Natal. They eventually became separate kingdoms of the Zulu, the Xhosa, ${ }^{5}$ the Swazi, Mpondo and Thembu of today (Giliomee \& Mbenga 2007:37). From 1818 to 1828 , King Shaka ruled and established his (Zulu) kingdom in the northern part of KwaZulu-Natal (between the Tugela and Pongola Rivers), incorporating all the other chiefdoms in that area.

Visagie (2012:97) quite rightly argued that these invasions and migrations can also be called colonisation. We refer to it as 'unofficial colonisation'.

\section{Clarification of some 'misconceptions'}

Much of what has been said under the previous sub-heading, is derived from 'evidence' like artefacts, tools and weapons that have been discovered in the country and linked to specific eras in history. It is not derived from noted evidence, as the mentioned people groups were part of an oral culture where (almost) nothing was noted on paper, but was orally related from generation to generation. That is the reason why the migrations are referred to as an 'unofficial colonisation' we can also call it the first colonisation of this country.

In contrast to that, the Europeans who landed in the Cape and who invaded it from the south formed part of a generation in which documentation played an important role. This could be one of the reasons why the invasion of Africa from the south was referred to as a colonisation, while the migrations from the north almost went by unnoticed, implying that the invaders or migrators (not immigrants) were part of the country's original populace - the indigenous people.

\section{A few remarks need consideration:}

- The original inhabitants (indigenous people) of the southern parts of Africa did not claim this part of the continent to be their official or legal property, as a great contingent of them was nomads. They were in fact just roaming the territory. There were, however, certain groups occupying specific areas, specifically close to water, like the pastoral Khoekhoe(n) tribes, but without a formal political structure or demarcation of land.

- Certain black people groups migrating to this part of Africa did, however, claim certain parts of the land to be theirs and therefore established kingdoms for themselves, as has already been referred to. These kingdoms had the implication of claiming a certain area as the sole property of the chief and his adherents or

5.According to Giliomee and Mibenga (2007:33), there is no real difference between the Xhosa and Zulu people groups as we know them today. The difference between the Xhosa and Zulu people groups as we know them today. The difference between
them originated from the settlers who distinguished between the two groups living in the Cape and Natal. 
clan. Should another group cross the borders of that demarcated land, then confrontation would take place, mostly in the form of a battle.

- As the numbers of black people in the southern part of Africa increased rapidly, these groups expanded more to the south of the country. As they expanded, they regarded more parts of the land as belonging to themselves.

- The Europeans in the south expanded to (invaded) their immediate north and especially to the east of the country. This brought them to the western side of the Fish River, where they met or clashed with a black people group, called the Xhosa, who arrived on the other side of the river. This happened in 1770 (Giliomee \& Mbenga 2007:75).

- From 1834, the Afrikaner group (also called Voortrekkers at that time) invaded the country firstly to the eastern parts (presently KwaZulu-Natal) and then to the northern parts as far as the Limpopo River, being almost in constant battle with the black migrants, conquering the migrants' claimed territory.

- The southernmost part of Africa, therefore, was initially officially invaded by colonisers, while the rest of the present South Africa was initially and 'unofficially' invaded by black people groups, before the white people later took it from them in battle. After 1852, most of South Africa up to the Limpopo River was conquered by white people.

- 1880 saw four white polities in South Africa, namely the Cape Colony and Natal (under British reign) and the Oranje-Vrijstaat (Orange Free State) and the ZuidAfrikaansche Republiek (South African Republic) - under Afrikaner reign (Chanaiwa 2000:194). The black people groups living in all four of these areas were dominated by the white people, as a 'policy of severely unequal segregation' was imposed on them (Betts 2000:314).

- The majority of the original (indigenous) people of the land - the Khoikhoi - was forced out of most of the country to the southern and south-western parts to make a living there. Some of them were incorporated by especially Xhosa Chiefdoms, and their children became Xhosa (Giliomee \& Mbenga 2007:74).

- South Africa thus experienced an 'official' invasion by the Europeans and an 'unofficial' invasion by the migrants both of them devastating to the indigenous people of the country, as well as to each other. Adhikari portrayed two phases of destruction, one by the earliest farmers and the second by the Europeans:

- Phase 1: Historically, the destruction of Cape San societies can be viewed as part of a series of overlapping, essentially concentric, global movements of violent subjugation that were often genocidal in nature. The broadest of these is the 12000 year history of the absorption, displacement and destruction of hunter-gatherer communities by farmers. (Adhikari 2010:20)

- Phase 2: San (Bushman) society in the Cape Colony was almost completely annihilated during the eighteenth and nineteenth centuries as a result of land confiscation, massacre, forced labour and cultural suppression that accompanied colonial rule. (Adhikari 2010:19)

\section{Official colonisation ${ }^{6}$}

As the two previous sub-headings referred to people groups who roamed the continent and reached the southern part of it by land, the colonisation referred to under this sub-heading originated from Europe and reached the southern parts of the continent by sea. The invention of the compass by the end of the 13th century made it easier for people to explore. Approximately two centuries later, the first voyagers to test the new invention on sea were the Portuguese. In 1486, Bartholomew Diaz sailed around the southern point of Africa, followed by Vasco Da Gama in 1497. The latter set foot ashore at both present-day St Helena Bay and Mossel Bay and traded with the Khoikhoi people. Close to the end of the 16th century, the Dutch became a 'major sea power' (Giliomee \& Mbenga 2007:40). In 1584, they sent Jan Huygen van Linschoten by sea to India, followed by Cornelis and Frederik de Houtman in 1595.

In the middle of the 17th century, the Dutch, with their home base in Amsterdam, had the 'largest trading enterprise' in the world (Giliomee \& Mbenga 2007:40), called the Vereenigde Oostindische Compagnie (VOC), established in 1602 (cf. Mitchell 2007:49). Their most important trading partners were (the present-day) India, Malaysia and Indonesia, and the best way to reach them was by sea. In 1619, the VOC established a regular government in Jakarta (on the Java Island of Indonesia, seized by the VOC), which became the capital of the Eastern Empire of the VOC, and renamed it to Batavia. ${ }^{7}$ The VOC did not pay their employees well, which opened the way for theft and corruption of which Jan van Riebeeck was a good example. Being an employee of the VOC, he held a post in Japan, but was recalled and fined because of 'private trading' (Giliomee \& Mbenga 2007:41).

Because of the long journey on sea with no fresh meat, fruit and vegetables, many of the sailors developed scurvy, prompting the need for a halfway station, which could easily be the southern part of the African continent. In 1650, the directors of the VOC, called the Heeren XVII, then decided to establish a refreshment station for the passing ships at Table Bay (named by Joris van Spilbergen in 1601) - then called the Cape, and in the next century known as Cape Town (Giliomee \& Mbenga 2007:42).

Whereas it was seemingly the intention of the VOC to only establish a halfway station at the Cape, Van Riebeeck soon realised that the land had immense possibilities and only a year after they had landed in the Cape, he released nine Company servants to start full-time farming to the eastern side of Table Mountain. The halfway station became a colony (cf. Pearson 2012:99-138). The colonisers brought with them

6.Note is taken of countries like Angola and Cameroon that were also both being colonised by more than one coloniser, though one of the colonisers only ruled for a short time span.

7.According to Giliomee and Mbenga (2007:42), the Cape was effectively governed from Batavia until 1731. 
the Western culture and Western 'intellectual baggage' (Giliomee \& Mbenga 2007:42) like the Roman-Dutch Law, the Reformed religion (the Reformed Church was based on Calvinist dogma) and capitalism - ideas foreign to this part of the world. From Batavia, the Dutch borrowed slavery and the display of wealth (Giliomee \& Mbenga 2007:45). This resulted in almost every wealthy person having slaves or 'servants' (cf. Viljoen 2001:28-51).

In 1795, the once-mighty VOC was on the verge of bankruptcy. Britain had founded the British East India Company and decided to take control of the Cape as a halfway station to the East. In June 1795, the fleet of Vice-Admiral Elphenstone arrived at Simon's Bay and, with the help of the main British fleet that arrived there on 03 September, they conquered the Cape at the Battle of Muizenberg. Having seized the Cape from the VOC in 1795, the British returned the colony to the Dutch government in 1803 when peace had been concluded with the French after the Treaty of Amiens. In 1806, however, with the beginning of the Napoleonic Wars, the British again took the Cape in order to protect the sea route to their Asian empire. This time the battle took place at Blaauberg.

From 1806 onwards the Cape would be a colony of Britain. Almost a century and a half of Dutch domination in the Cape came to an end - interestingly South Africa was the only country in Africa being colonised by the Dutch. This was the introduction to almost a century and a half of English domination up to 1961 when South Africa became an independent Republic, after being a Union under British supervision for half a century - from 1910.

\section{Internal colonisation}

After being colonised 'unofficially' by the migrants from the north, as well as having two 'official' colonisations by the Europeans from the south, this country had to face a fourth 'internal' colonisation before it would gain its freedom. The Republic of South Africa from 1961 onwards was just a continuation of the rule of the National Party, which had already started in 1948. This white Afrikaner rule without any black or mixed race representation - this time independent of the supervision of Britain - was nothing else but a next phase of colonisation of this country, and this was maybe the harshest of them all. This colonisation would end only in 1994.

\section{A new people group and a new language}

The Cape Coloureds, or mixed race people as they are known today, was not a people group in the Cape when the groups from the north and the south arrived in this part of Africa. The origins of the mixed race people can officially be traced back to the arrival of the Dutch in South Africa. Firstly, there was mixed offspring of Dutch and Malay slaves who arrived at the Cape in 1657. The Settlers and the soldiers who came to the Cape had mixed offspring with the Khoikhoi, the San and later also with the Xhosa people. The Indians who came to the Cape also contributed to the gene pool (Khan 2009). According to Jenkins (1996), the people groups in the present-day South Africa that can be classified as coloureds or mixed race people are:
- the Cape Malay, living in the Western Cape and Namibia

- the Griqua mixed race who live in the vicinity of Kimberley in Griqualand, which forms part of the present-day Western Cape

- the Rehoboth community in Namibia.

The mixed race people in South Africa have many ambiguities and variances, while their skin colour varies from black or brown to white. Some of them have Afrikaans names and surnames, while others have English, Indian or other surnames. The mother tongue of most of them is Afrikaans, as is the mother tongue of most of the remaining Khoisan people living in the Cape.

Among the Dutch and the new people group, a new language emerged, which could be called pidgin ${ }^{8}$ Dutch. As the Dutch language, spoken in the Cape, gradually changed from the language being spoken in the Netherlands, the people started to call it the African language or Afrikaans. This common language showed differences from the Dutch being spoken in the churches, in law courts and in the schools in the Cape. The new language also borrowed words from the local people. As early as 1685 (less than 30 years after the arrival of the Dutch in the Cape), a senior official already warned the people against a corruption of the Dutch language (Giliomee \& Mbenga 2007:71). Today, Afrikaans is the third most common language, after Zulu and Xhosa, spoken in South Africa by $13.5 \%$ of the people (South Africa.Info 2015; cf. Giliomee 1996:59-85).

It is already noted that Africa was the origin of modern mankind, but not of modern language. However, in a very interesting study conducted by Quentin Atkinson on phonemic diversity within 500 different languages, he concluded that central and southern Africa 'could represent either a single origin for modern languages or the main origin under a polygenesis scenario' (Atkinson 2011:347). It is therefore not a strange phenomenon that Afrikaans was also created in this part of the continent.

\section{A 'rainbow nation'9}

This designation was given to the nation in 1994 by the then Archbishop Desmond Tutu (cf. Brits 2012:550) and was quoted by Dr Nelson Mandela in his inauguration as president of South Africa, when he said:

We have triumphed in the effort to implant hope in the breasts of the millions of our people. We enter into a covenant that we shall build the society in which all South Africans, both black and white, will be able to walk tall, without any fear in their hearts, assured of their inalienable right to human dignity - a rainbow nation at peace with itself and the world. (African National Congress 1994)

Baines (1998) 'explained' that Tutu was most probably referring to the Old Testament story of the flood in which the

\footnotetext{
8.The Oxford Dictionaries (2015) supply a broad definition of the word pidgin: "A grammatically simplified form of a language, typically English, Dutch, or Portuguese, some elements of which are taken from local languages, used for communication between people not sharing a common language.'
}

9.See Tshawane (2009), who wrote his thesis on the subject of a rainbow nation. 
rainbow symbolised the promise of God never to judge humankind this way again. It could also resonate with the symbolism of the rainbow which indigenous cultures in South Africa have. The Xhosa, for instance, regard the rainbow as signifying hope as well as the assurance of a bright future. From this, Baines derived that the metaphor of the rainbow nation 'both informs and reinforces the vision of nation building' (Baines 1998; cf. also Alexander 2000:23). He also saw a secondary metaphor of the rainbow, in that its spectrum of colours is portraying the multicultural society in South Africa. Nevitt (2015) concurred by stating that the colours of the rainbow are capturing the diversity that South Africa has in race, tribe, creed, language and landscapes. Walker stated that the goal of a rainbow nation was to 'produce a new kind of South African' (Walker 2006:141). Giliomee and Mbenga (2007) reflected on the immediate effects of this concept:

After the first free election in April 1994 South Africans shared a single nationality. A common citizenship and a commitment to tackle the future together. The pre-amble to a widely acclaimed constitution called on citizens to remember both the suffering and the achievements of the past. The national flag and the anthem successfully blended historic symbols and songs. (p. 433)

While this concept seemed to be filled with so many positive characteristics (cf. Sparks 2003:329), Meiring, just 2 years after Giliomee and Mbenga (2009), warned against the simplistic way of just referring to the South African nation as a rainbow nation:

The multilinguistic and multicultural nature of South Africa makes being South African, and trying to explain to an outsider what the term actually means, complicated. Because South Africa is a heterogeneous society consisting of many communities, each with their typical cultures and language varieties, sometimes the only common ground for identity is that a South African lives in South Africa. (pp. 280-281)

Apartheid effectively created two separate political communities - one predominantly white people and the other one predominantly black people - living together in one country (cf. Posel 2001:52ff). In this country where almost every race waged war against each other - not only black people against white people but also white people against white people and black people against black people - it would almost be impossible to bring all the hatred to an end and make a fresh new start (cf. Marx 2002:53-55). This would be impossible had the country not a leader in the likeness of Dr Nelson Mandela (cf. De Klerk 2003:322-334). After being imprisoned by the white regime for 27 years of his life, he walked out a free man in 1990 and became the first president of the Democracy in 1994. From the outset, his approach was reconciliatory (cf. Guelke 1999:192) and his words and actions were proof of that (De Klerk 2003:323).

With one of the most liberal constitutions in hand (cf. Brits 2012:549), which 'guarantees the rights of individuals rather than collectives such as cultural and ethnic groups' (Baines 1998), the new Democracy initially took small steps in the right direction (Sparks 2003:330). Although maybe unintentionally, the constitution incorporated three fundamental Christian values, namely dignity, equality and freedom (Vorster 2005:477). Initially, the different races struggled to get along with each other as distrust and enmity were the order of the day (Vorster 2005:481). Despite this, the idea of a rainbow nation was well accepted during the time of Mandela as he was the big freedom icon (cf. Brits 2012:579). The shift he propagated was 'from a racially constituted system of inequality and cultural identity to a national identity constituted as culturally diverse but with equality based on citizenship' (Baines 1998; cf. Simpson 1994:463-474). He, therefore, took the first steps to building a new nation (cf. Alexander 2000:23). ${ }^{10}$

During the time of Thabo Mbeki, Mandela's successor, the emphasis seemed to have moved away from the unity of the people of the land, to a preference for transformation (Vorster 2005:483) and economics (Dickow \& Møller 2002:176; cf. Iheduru 2004:1-30). During his time it also became clear that the ANC had not yet transformed its members to be part of a united country, as many of them believed and acted as if they were still in the struggle. There were also white people groups who did not want to adapt and who tried to destabilise the country (like the events that happened at the 53rd ANC National Conference in Mangaung 2012). This caused more polarisation as the acts of a small group of one race can cause distrust against the race as a whole. Affirmative action contributed to the polarisation of the different groups (Dickow \& Møller 2002:176). Many white people abandoned the country because of that (Dolby 2001:6).

There was, however, one element that would help the society to join forces: Poor government performance (Giliomee \& Mbenga 2007:437). Slowly but surely, the different components of society started to join forces in forging a rainbow nation from the bottom to the top, as government was unable to do it from the top down. Throughout the country, the media was utilised to convey the message of a single rainbow nation - a unified nation. SABC TV used the slogan Simunye, meaning We are one. The South African Breweries propagated a certain alcoholic drink with the words, One Beer, One Nation - a drink that is to the present day connected to South African rugby.

The notion of rainbowism, however, had Africanisation in mind (cf. Marx 2002:55; Prah 1997:11-16), reflecting the demographic character of the nation, which consists of more than $80 \%$ black people (Statistics South Africa 2014). ${ }^{11}$ Although the language that was bred in South Africa, was Afrikaans, the black people in the country saw (and still see) it as the language of the oppressor (or even as a European language). As there is no unified language in the country, the language of communication is English. Despite this,

10.Nation-building is understood as the: social process of transforming an underdeveloped, poor and divided society into a community with peace, equal opportunities and economic viability within which individuals enjoy dignity, basic human rights and the prospect to observe their own religion, tradition, culture and human rights and the prospect to observe their own religion, tradition, culture and language in harmony with other people who may function within other traditions
(Vorster 2005:474).

11.There are four broad groupings of black people in the country, of which the first two make up $90 \%$ of the population: The Nguni, consisting of the Zulu, the Xhosa, the Ndebele and the Swazi people; The Sotho-Tswana, that includes the Southern Northern and Western Sotho/Tswana people groups; The Tsonga; The Venda. 
government had decided on 11 official languages to assure that even a small people group like the Venda was covered. According to Rex (1995:31) the 'recognition of cultural diversity actually enriches and strengthens democracy'.

Lastly, it can be stated that South Africa is still the country in Africa with the most white inhabitants - approximately 4.5 million (according to the 2011 Census in South Africa. info 2015) - even after colonisation and forming part of this rainbow dream of proponents like Nelson Mandela and Desmond Tutu.

\section{Conclusion}

By reading the history of South Africa, it becomes clear that this country has its own unique story about colonisation. Having in mind what the term 'colonisation' entails, we can conclude that South Africa, in fact had four colonisers:

- About 2000 years ago: An unofficial colonisation by the black people groups from the north. This colonisation was ended in 1880 when the country was divided into four polities, two being ruled by the British and two by the Afrikaners.

- 1652: An official colonisation from the south by the Dutch VOC. This colonisation came to an end when Britain finally took the country from the Netherlands in 1806 (actually for the second time).

- 1806: An official colonisation of the country by Great Britain. This era came to an end when the country became a Republic in 1961.

- 1961: An internal colonisation of the country by the white Afrikaners, which ended in 1994 when the country became a Democracy.

All the different people groups that arrived in the Cape and started to 'mingle' with each other and with the indigenous people, saw the birth of a new people group in the country, called the mixed race people. Added to that, a new language also emerged, which can at first be characterised as 'Pidgin Dutch'. This language would become one of the dominant languages in the country, but is regarded by most black people as the language of the oppressor.

Fortunately, after the fourth and last colonisation of the country and after much pain and oppression and apartheid, the country became a Democracy, establishing a rainbow nation where everybody has equal rights.

Amidst much critique on the colonisation of South Africa and for that matter, on Africa as a whole, the aim of this article was to look at some unique features of the colonisation. As it is obvious that the European and Afrikaner colonisations can and will never be justified, this article also wanted to add some perspective on the migrations or invasions from the north of the continent, which can also be classified as some sort of colonisation and which are mostly overlooked or ignored.

The unique features of colonisation in South Africa, discussed in this article, had no intention of putting colonisation in a good light, but merely indicated the outcomes thereof for this country.

\section{Acknowledgements Competing interests}

The authors declare that they have no financial or personal relationships which may have inappropriately influenced them in writing this article.

\section{Authors' contributions}

E.O. and W.H.O. equally contributed to the research and writing of this article.

\section{References}

Adhikari, M., 2010, 'A total extinction confidently hoped for: The destruction of Cape San society under Dutch colonial rule, 1700-1795', Journal of Genocide Research 12(1\&2), 19-44. https://doi.org/10.1080/14623528.2010.508274

African National Congress (ANC), 1994, Speeches: Statement of Nelson Mandela at his inauguration as President, viewed 03 September 2015, from http://www.anc.org. za/show.php?id=3132

Alexander, N., 2000, 'Manuel Castells and the New South Africa', Social Dynamics 26(1), 18-36. https://doi.org/10.1080/02533950008458683

Atkinson, Q.D., 2011, 'Phonemic diversity supports a serial founder effect model of language expansion from Africa', Science 332(6027), 346-349. https://doi.org/ $10.1126 /$ science. 1199295

Baines, G., 1998, 'The rainbow nation? Identity and nation building in post-apartheid South Africa', Mots Pluriels 7, viewed 29 April 2015, from http://www.arts.uwa. edu.au/MotsPluriels/MP798gb.html

Betts, R.F., 2000, 'Methods and institutions of European domination', in A.A. Boahen (ed.), General history of Africa, vol. 8: Africa under Colonial Domination 18801935, reprint, pp. 312-331, UNESCO Publishing, Paris.

Boahen, A.A., 2000, 'Africa and the colonial challenge', in A.A. Boahen (ed.), General History of Africa, vol. 8: Africa under Colonial Domination 1880-1935, reprint, pp. 1-18. UNESCO Publishing, Paris.

Brits, J., 2012, 'Suid-Afrika ná apartheid, 1994-2004', in F. Pretorius (ed.), Geskiedenis van Suid-Afrika: Van voortye tot vandag, pp. 549-580, Tafelberg, Cape Town.

Chanaiwa, D., 2000, 'African initiatives and resistance in Southern Africa', in A.A. Boahen (ed.), General History of Africa, vol. 8: Africa under Colonial Domination 1880-1935, reprint, pp. 194-220, UNESCO Publishing, Paris.

De Klerk, B.J., 2003, 'Nelson Mandela and Desmond Tutu: Living icons of reconciliation', Ecumenical Review 55(4), pp. 322-334. https://doi.org/10.1111/j. 1758-6623.2003.tb00467.x

Department of Education, 2000, National curriculum statement, Department of Education, Pretoria.

Dickow, H. \& Møller, V., 2002, 'South Africa's "Rainbow People," national pride and optimism: A trend study', Social Indicators Research 59, 175-202. https://doi. org/10.1023/A:1016234504243

Dolby, N., 2001, 'White fright: The politics of white youth identity in South Africa', British Journal of Sociology of Education 22(1), 5-17. https://doi.org/10.1080/ 01425690020030756

Giliomee, H., 1996, 'Being Afrikaans in the New (multilingual) South Africa', New Contree 40, 59-85.

Giliomee, H. \& Mbenga, B., 2007, New history of South Africa, Tafelberg, Cape Town.

Guelke, A., 1999, South Africa in transition - The misunderstood miracle, IB Tauris, London.

Heath, E., n.d., Berlin Conference of 1884-1885, in Oxford Reference, viewed 28 August 2015, from http://www.oxfordreference.com/view/10.1093/acref/ 9780195337709.001.0001/acref-9780195337709-e-0467

Heldring, L. \& Robinson, J. A., 2012, Colonialism and Development in Africa. Nationa Bureau of Economic Research Working Paper, 18566, viewed 28 August 2015, from http://www.nber.org/papers/w18566.pdf

Iheduru, O.C., 2004, 'Black economic power and nation-building in post-apartheid South Africa', Journal of Modern African Studies 42(1), 1-30. https//doi.org/ $10.1017 / \mathrm{S} 0022278 \times 03004452$

Jenkins, O.B., 1996, The Coloureds of South Africa, viewed 15 May 2015, from http:// www.grmi.org/ jhanna/obj08.htm

Khan, R., 2009, Gene expressions: Who are the Cape Coloureds of South Africa?, viewed 23 April 2015, from http://blogs.discovermagazine.com/gnxp/2009/06/ who-are-the-cape-coloureds-of-south-africa/\#.VTjipSGqpBe

Marx, C., 2002, 'Ubu and Ubuntu: On the dialectics of apartheid and the nation', Politicon: South African Journal of Political Studies 29(1), 49-69. https://doi. org/10.1080/02589340220149434 
Meiring, B., 2009, 'Proudly South African: A toponymical excursion', Language Matters: Studies in the Language of Africa 39(2), 280-299. https://doi.org/ Matters: Studies in the Langud

Meyer, A., 2012, 'Suid-Afrika se oerverlede', in F. Pretorius F (ed.), Geskiedenis van Suid-Afrika: van voortye tot vandag, pp. 17-36, Tafelberg, Cape Town.

Mitchell, L.J., 2007, "This is the mark of the widow": Domesticity and frontie conquest in colonial South Africa', Frontiers 28(1\&2), 47-76. https://doi.org/ 10.1353 /fro.2007.0034

Nevitt, L., 2015, Rainbow nation? CapeTownMagazine.com., viewed 30 April 2015 from http://www.capetownmagazine.com/whats-the-deal-with/rainbow-nation/ 125_22_17853

Oliver, W.H., 2014, 'Reconsidering the skin colour (race) of Jesus and his ancestors', Journal of Early Christian History 4(2), 95-115.

Oppenheimer, S., 2003, Out of Africa's Eden, Jonathan Ball Publishers, Jeppestown.

Oxford Dictionaries, 2015, viewed 04 September 2015, from http://www. oxforddictionaries.com

Pakenham, T., 1991, The Scramble for Africa, Random House Inc., New York, NY.

Pearson, S.A.G., 2012, 'Colonialism and the African experience', in V.B. Khapoya (ed.), The African experience, pp. 99-138, Longman, New York, NY.

Posel, S., 2001, 'What's in a name? Racial categorizations under Apartheid and their afterlife', Transformation 47, 50-74.

Prah, K.K., 1997, 'Africanism and the South African transition', Social Dynamics 23(2), 11-16. https://doi.org/10.1080/02533959708458631

Rex, J., 1995, 'Ethnic identity and the nation state: The political sociology of multicultural societies', Social Identities 1(1), 1-34. https://doi.org/10.1080/13504630. 1995.9959424

Simpson, M., 1994, 'The experience of nation-building: Some lessons for South Africa', Journal of Southern African Studies 20(3), 463-474. https//doi.org/10.1080/
03057079408708414
South Africa, 2015, Ancient people of the land: The Khoisan people of the Northern Cape, viewed 30 January 2015, from http://www.southafrica.net/za/en/articles/ entry/article-southafrica.net-the-khoisan-people

South Africa.Info, 2015, The languages of South Africa, viewed 18 May 2015, from http://www.southafrica.info/about/people/language.htm\#.VVnjU_mqpBc

Sparks, A., 2003, Beyond the miracle: Inside the New South Africa, Jonathon Ball, Johannesburg.

Statistics South Africa, 2014, Statistical release P0302. Mid-year population estimates, Pretoria.

Tshawane, N.J., 2009, 'The Rainbow Nation: A critical analysis of the notions of community in the thinking of Desmond Tutu', Doctoral Thesis submitted at the Department of Systematic Theology at the University of South Africa, Pretoria.

Vestergaard, M., 2001, 'Who's got the map? The negotiation of Afrikaner identities in Post-Apartheid South Africa', Daedalus 130(1), 19-44.

Viljoen, R., 2001, 'Aboriginal Khoikhoi servants and their masters in colonial Swellendam, South Africa, 1745-1795', Agricultural History 75(1), 28-51. https:// doi.org/10.1525/ah.2001.75.1.28

Visagie, J., 2012, 'Migrasie en die gemeenskappe noord van die Oranjerivier', in F. Pretorius (ed.), Geskiedenis van Suid-Afrika: Van voortye tot vandag, pp. 97-116, Tafelberg, Cape Town.

Vorster, J.M., 2005, 'Nation-building in South Africa: Has progress been made?', The Ecumenical Review 574, 473-491. https://doi.org/10.1111/j.1758-6623.2005. tb00568.x

Walker, M., 2006, 'Rainbow nation or new racism? Theorizing race and identity formation in South African higher education', Race Ethnicity and Education 8(2), formation in South African higher education', Race Ethn

Weldon, G., 2009, 'Memory, identity and the politics of curriculum construction in transition societies: Rwanda and South Africa', Perspectives in Education 27(2), 177-189.

Wilmot, M. \& Naidoo, D., 2011, "Behind the doors of learning": The transmission of racist and sexist discourses in a History classroom', Perspectives in Education 29(2), 28-38. 